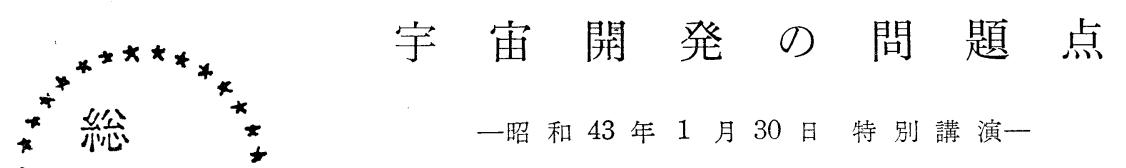

日 本 学 術 会議 宮 地 政 司
宇宙空間研究特別委員会

\section{1. 問題の背景}

1-1 スプートニック・ショック

10 年前の 1957 年 10 月 5 日の夜明け前, 人類史上最初 の人工衛星がとんだ。ソ連が打上げたスプートニック 1 号である。突然のことだつたので全世界はアッとい つて驚いた。

その 2 年前の 1955 年の夏, ベルギーのブルッセルで 国際地球観測年 (IGY，1957年 7 月から1958年12月ま での間，国際協力によつて全世界的に地球物理学的諸 観測が実施された）の準備のための総会が開かれた。 その席上でアメリカの代表ニューオル博士は，IGYに 協力するためアメリカは人工衛星というものを打ち上 げ，大気圈外で諸観測を行なう計画があると公表し た。そして米国大統領アイゼンハワーの言葉を引用し た。「アメリカは科学の進歩のために全世界の科学者 にこれを捧げる」と。事実, 人工衛星は科学者のため に地球大気といら厚い壁の屝を開いたのである。

アメリカで最初に計画された人工衛星はバンガード 計画と呼ばれたもので, 径 $16 \mathrm{~cm}$ の球型で，わずか 1.5 $\mathrm{kg}$ の重さしかなかつた。その打上げ用ロケットが 10 億円もするというので驚いた。ところが，IGYが始ま つて最初に上つた人工衛星は, アメリカのものではな くソ連のものであつた。その重さが $80 \mathrm{~kg}$ あると聞い てまた驚いた。世界中の人々がソ連の実力を賞賛し た。

読者の多くはこのスプートニック・ショックを覚え ておられるであろう。あのときの驚嘆・感激・賞賛は 筆舌で尽せないほどであつた。そして波紋はあらゆる 方面に搪がつていつた。たんに科学技術の方面だけで なく，政治・経済・外交・軍事・教育と全世界をゆる がした。

人工衛星を打上げたといらことが，なぜそんなに大 騒ぎになるのであろらか。まず第一にそれは，その国 の持つ科学技術が高い水準にあることを示す。つぎに それを実施しえた工業力と経済力の偉大さを意味して いる。いわばこれら汇近代国家の象徴である。人工衛
星の打上げはそうした国家の権威を示したことにな る。ソ連が米国より秀れている感じを与えたところに 大騒ぎになつた原因があつたと思う。

だぶだぶズボンの貧農の国が，革命後50年たためう ちに，世界最高の科学技術の成果を示したのである。 その国内事情が秘密のためよく知られていないだけ に, 人々は一種の恐怖さえ覚えた。打上げまえからあ らゆる情報を流すアメリカと, 打上後でないと何もの も公表しないソ連とは10年後の今日も変わらない。

それはそれとして，アメリカではなぜソ連に先きを 越されたかで，世論がわいた。各方面でその対策が論 議された。教育問題まで飛び出し, 科学教育など大き な改訂が加えられた。わが国でも, 関係者が国会に呼 ばれ参考意見を徵された。各国とも大同小異で, 真剣 に対策を講じたようである。

アメリカではそれ以来, 宇宙開発予算を年々倍加し ていつた。そして，ここ当分のところ年額約 2 兆円の 予算が宇宙開発のために計上されている。ヨーロッパ では, 米・ソに対抗して, 英・仏・独・伊などが中心 に約 10 ケ国ほどが，ヨーロッパ打上げ開発機構 (EL DO) とヨーロッパ宇宙研究機構 (ESRO) をつくり, 共同で研究開発を進めることになつた。わが国では, ささやかながら IGY 以来, 小型口ケットによる宇宙 科学研究を続けてきた。10年間に約 200 億円が投入さ れ，最近では年額で 40 50 億円程度が計上されてい る。

\section{1-2 10年目の反省}

最初の人工衛星が打上げられてから，去年の 10 月で 満10年である。普通なら10周年の祝賀があるところで 何かすばらしい事件でも起こるのではないかと，一部 では大きな期待をかけていた。米国は月探検船アポロ をいよいよ打上げ試験をするだろら。ソ連はことによ ると人間宇宙ステーションを開設するのではないか。 今度は中国が大型口ケットを打上げるかも知れない。 日本もいよいよ人工衛星国の仲間入りができるだろ う。——などなどが期待であつた。 
ところが去年は惨々な厄年であつた。1月末にはア ポロ宇宙船が実験訓練中に火炎を起こして，3人の有 能な宇宙飛行士が燒死した。電気系統の不注意で飛ん だ火花が，船室内に張つてあつたベルクロ（カギ付布 地）に引火したのだときく。ベルクロは無重量状態に なつたとき，いろいろな品物が飛散しないためにそれ らを留めるため壁に張つてある布, それに室内は純酸 素ガスで満されていたので簡単に引火したらしい。遭 難したグリソム氏はその死を予想していたようにこん なことをいつている。「私は宇宙船内で死孖も知れ ない。それ研究開発の常だ。だが, 計画は進められ ねばならない」と。

4 月の下旬には, 今度はソ連で 3 人乗りの宇宙船ソ ユーズ号が, 地球 1 周の試験飛行を抢えて着陸直前 に, 制御装置の故障で墜落し，1 人の宇宙飛行士が犠 牲になつた。宇宙飛行では人類史上最初の惨事といえ よう。なくなつたコマロフ氏はわが国を訪机たことも あり，そのとき「月旅行は急ぐことはない。大切なこ とはいかに安全にこれをなしとげるかにある」といつ ていた。

以上のような人命事故の他に，わが国では 4 月に人 工衛星打上実験が失敗した。ラムダロケット (L4S) による人工衛星打上試験で, しかもその 3 回目の失敗 であつた。調查報告によれば, $1,2,3$ 号の事故はつぎ のようでめつた。

L4S-1 号 : 第 2-3 段結合部の切離し不良, デスピ ン（きりもみ停止操作）の作動不良。

L4S- 2 号 : デスピン不完全, 第 4 段事前に半分離。 L4S- 3 号 : 第 3 段不点火, 第 4 段事前に半分離。 その年の 8 月にはヨーロッパ機構 ELDO で開発し たヨーロッパ1号の打上試験でも, 第 2 段コラリー

(フランス製)に不点火のため失敗している。

まことにグリソム氏のいらように, 研究開発には失 敗は付きものである。だからといつて失敗してもよい というのではない。ただ，それらは貴重な資料として 生かされなければならない。東京大学の上記の失敗も それぞれ貴重なデータとなつたと思うのだが，同様な 失敗が繰り返えされているようで残念に思う。この失 敗が引金になって，大学に拉けるロケット開発に批判 が起こつた。

たまたま数年前から, 各省庁ではそれぞれの所管事 項として, 人工衛星の実利用について研究を進めてい た。通信衛星についてはアメリカとの宇宙中継実験を 行ない, またわが国として独自の研究も行なつた。航 海衛星については研究所が設置され進められている。
気象・測地の分野でも鋭意研究されつつあつた。一方 ではその打上に応ずるため, 人工衛星打上用の大型口 ケットの開発についてシステム・デザインが進められ た。

大学と各省庁とがそれぞれ進めている宇宙活動を, 総合的に無䭾なく進めるためにいかにすべきが問題と なつた。宇宙開発審議会では諮問に答えて, 国として どのように考え，何と何をどのような体制で実施する かについて，一応の答申を出した (1967年12月)。だ が，なお多くの問題がその中に含まれているようであ る。

それらの問題点にふれるのが本稿の主旨であるが, そのまえに，宇宙開発によつて何がえられたかをつぎ にのべようと思う。10年の成果である。これは，なぜ 宇宙開発を進め齐ばならぬかを如実に示すであるう。 それにつけ，ジョンソン米大統領はいつている。「宇 宙開発における米国の目的は平和である。たんなる国 威発揚ではない」と。また, ヨーロッパ各国の宇宙開 発視察報告はいずれも「バスに乗りおくれるな」が合 言葉のようであるといつている。わが国などもその観 があるが，私は一国の独立は科学技術の独立がなくて は達せられないからだといいたい。

\section{2. 宇宙開発の意義と現状}

\section{2-1 宇宙開発の歴史的位置}

人類の知識の発展, ひいては文化の向上の跡をたど ると, 地域社会の拡大が文化向上の大きな要因になつ ているように思う。地域と地域, 国と国というように 相互の交流によって進歩していつたことは歴史に明ら かである。いまはそれが地球全体に拡大した時代とい つてよからう。その意味で宇宙開発は今度は地球を宇 宙空間にまで拡大し, 新しいエポックを作るものであ るといえよう。

古代文化は，ギリシャ・中国・印度などいずれも， 主として個立した局地的文化として発達している。そ れが12世紀ないし13世紀にかけ, 十字軍や蒙古軍の移 動により東西文化の 交流となり, 文芸復興（知的復 興）の新しい時代をまねいた。

16 世紀の新大陸の発見は, 今日のアメリカを人類に 導いた。この発見は科学への信頼と開拓者精神とによ り達成された。その精神が現在の合衆国の繁栄をもた らすバックボーンになつているという。

19世紀の産業革命は交通機関の発達をもたらした。 そして電信による通信業務の発展と合わさつて, 全地 球を一つにまとめるのに役立つた。文化は世界中に拡 大し，現在の国際社会を生む基になつた。 
そしていま人工衛星や宇宙船が出現した。上記のよ らな見方をすれば，これらは人間の支配する領域を宇 宙空間に抎大するものである。それこそ21世紀への胎 動であり，そこに宇宙空間からえられた知識に基づく 新しい文化が栄えることであろう。

知識を追求するのは人間性である。それを全宇宙に 直接求めることにより，人間注自らを宇宙の中再発 見するであろう。それによつて，思想も政治も経済も 外交も基本的に注わらざるを得ないだろう。地球対 宇宙といらことになれば，地上の全人類が一体になつ て宇宙の経営にあたるべきだと考える。このように考 えるなら代，宇宙開発注果しなく無限の可能性をもつ といえるであろう。

\section{2-2 宇宙開発のあゆみ}

宇宙開発ですぐ問題にされるのは, 兵器としての口 ケットやその応用などとの関連である。そもそもロケ ットそのものの由来汭戦争から出発しているからであ ろら。

ロケットは古くは蒙古軍が使つた火矢治まるとい らが, 近代的な兵器として発展したのは第 2 次世界戦 争で使われた V2 ロケットからである。このことから 宇宙研究注兵器研究に通ずるようにいわれるのである ら。だが，V2 ロケットの前身は高層気象研究用とし て開発されたものであつた。それをドイツでは苦しま ぎれにロンドン攻撃用に使つたのであつた。いずれに しても, 戦争はあらゆるものを利用する, 有効なもの ほど利用が多い，だからといつてロケットを兵器とき めつけて宇宙開発に反対するのは穏当ではない。

1957年 58年の IGY に人工衛星が登場してから， いまでは，観測ロケット・人工衛星・宇宙船などが自 然科学研究にはなくてはならないものになつてしまつ た。天文・気象・地球物理・物理・化学・生物など, いずれもそうである。ことに地球物理学的研究は宇宙 空間の諸性質を明らかにした。それは中学・高校の地 学の教科書を書き直さなければならないほどに新しい 事実が数多くわかつてきた。

こらなると，打上げの技術とも連携して，この宇宙 空間を実用目的のため利用すべく，開発が行なわれ た。通信・気象・航行・測地の諸衛星は国際的にひろ く活用されており，新たに資源衛星が登場しようとし ている。これらはいずれも人間社会へ計り知れない利 益をもたらすものである。また直接利益をもたらすも のではないが, 空飛ぶ天文台・太陽観測所・地球物理 観測所があつて，地上観測の欠点を補つている。将来 はこの方が主役になるかも知えない。
1961年 4 月には，ガガーリン宇宙飛行士が人間衛星 船ボストーク号でとんで，人間の宇宙進出の可能性を 確立した。考えようによつてはこれは軍事的に大きな 価值があるのかも知れない。航空機では他国の領空を: 勝手汇飛行することは許されないが，人工衛星では白: 由になつているからだ。

当時の米国大統領ケネディは, アメリカは国策とし て，1960年代の終わりまでにアメリカの人間を月に送 ると宣言した。それ以来アポロ計画が国策として推進 されることとなつた。現在ベトナム戦争でアメリカで は予算が筑屈になつているにかかわらず，この月計画 だけは削減されないのもそのためであろう。

人間の宇宙進出は, その後急速に発展した。宇宙船 の操綐, 人間の宇宙船外での作業, 宇宙船同志の連結 分離など, 人間の支配する領域の拻大のための努力と いえよう。

1967年, 宇宙空間や天体を悪用しないようにと, 宇 宙平和条約が縍結された。

\section{2-3 各国の宇宙活動の現状}

以上にのべたような訳で，各国はいずれも宇宙活動 を重視し，先進国といわれる国々では，国策としての 研究開発課題として推進しているようである。いずれ にせよ，宇宙開発は巨大科学である。そこで各国の宇 宙活動がいかなる規模で進められているか。これを 知るには，それに投資された 研究開発費の額が参考 となろう。

最大の投資を行なつているアメリカについて1967年 度の予算を例としてその大勢をみるとつぎのようであ る。アメリカの国民総所得は約 8,000 億ドルだが，国 家予算はその $17 \% の 1,350$ 億ドルである。その内の大

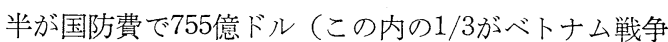
費）である。宇宙開発費は53億ドルであるから，国費 全体の中に占める割合は $4 \%$ 弱である。国防費を除い た国費に対する割合では，実に 9 \%溺になる。邦貨に して約 2 兆円である。

ソ連での経費は不明である。多分アメリカと大同小 異であろら。いずれにしても，年間 2 兆円前後が宇宙 開発に投入されていると考えてよかろら。

これに比して，その他の国では桁ちがいに小さい。 フランスでは人工衛星を打上げているが，そのロケッ トの開発は軍で行なわれているので，その経費ははつ きりしていない。合計して 1,000 億前後との推定があ る。ヨーロッパでも英・独などの主要国では，それぞ れ年額 200 億円 300 億円の予算である。

日本では1957年度が50億円あまり，1958年度は大幅 
亿增えて70億円を越している。1958年度の内訳では, 東大 30 億, 科学技術庁 32 億, 電波研究所 7 億が主なむ のである。他に通産省関倸之運輸省関倸にそれぞれ 1.5億円がある。

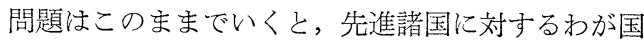
の宇宙活動の格差がますます大きく開くのではないか と心配である。米・ソは互に「追つけ，追こせ」の合 言葉で競争し一忘は均衡している。ヨーロッパ各国は 欧州機構を作つて米ソを追う姿勢である。

学術研究上で宇宙活動はいまでは不可欠のものであ る。また将来実益上宇宙利用も大いに推進すべきもの である。わが国の国際的地位からいつても，応分の宇 宙活動を行なつて国際的に寄与するのは当然だと思 ら。とくに有数の工業国であるわが産業界が，宇宙活 動からえられた技術の波及効果の影響を受けないはず はない。工業立国のわが国である。一応の水準までは 宇宙活動を盛り上げるべきことは, 国の独立と繁栄の ためにも放置できないことと考えるのである。幸に， 国として新年度から本格的にこの方面を推進すること に決定したようである。新らしい方針の下に大きな前 進を期待する次第である。

\section{1-3 地球の周辺空間}

\section{3. 宇宙科学の成果}

観測ロケットや人工衛星による観測からえられた宇 宙空間の諸現象は，その一つ一つが驚きであつた。そ して従来の知識——地上からの観測だけの知識が，い かに貧弱なものであるかを思い知らされたのであつ た。

たとえば，地球上の大気はどの高さまで存在してい るかといつたことさえ，従来は非常に不確かであつ た。この点について新しく判明したところではつぎの ようである。まず地上の空気と同一の組成をもつ大気 は地上から約 $100 \mathrm{~km}$ まで拡がつている。それから上層 になると分子は解離を起こし, 電離を始め電離大気と

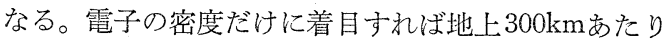
で最大密度になる。ところがイオンに着目すると種類 によつてちがう，この辺から地上 $1,000 \mathrm{~km}$ ありまで は $\mathrm{O}^{+}$が主役である。それからへリウム層 $\left(\mathrm{He}^{+}\right)$が 酸素層にかわる。その層の上限池上 $3,000 \sim 5,000$ $\mathrm{km}$ にある。それ以上になると水素層 $\left(\mathrm{H}^{+}\right)$となる。 この層の範囲は，太陽に面する側が地球半径の10倍ぐ らいであるが，太陽とは反対側では太陽風のために吹 き流されて，彗星の尾のよらに地球の尻尾になつてい る。その先端は少なくとも月の軌道（その距離池梂 半径の60倍) よりも外側にのびている。
地球大気の外側は次第に惑星空間に消滅するという のではなく，外界に対して画然と区別されている。地 球の電離大気注地球の磁場内に閉じこめられている。 その地球磁場の拡がりそのものは太陽風（太陽プラズ マ）に圧されて，上記の地球大気の限界が示すような 空間内に压しこめられているので，泣つきりした境界 がある。

人工衛星による発見の最初のものとして有名なバン アレン帯は, この地球磁場にとらえられている高エネ ルギー（高速）のイオン（主として陽子）や電子から なり，電離大気の中核帯である。殺人的放射線帯とし て宇宙飛行には危険千万な領域である。

地球大気の範囲 (磁氞圈)より外を惑星空間とよ ぶ。この空間は高度の真空であるが，完全な真空では ない。実は太陽大気が，非常に稀薄で岕るが，地球 のずつと先をで挔つている。この太陽大気はプラズマ とよばれる。プラズマは，固体・液体・気体ともちが い，物質の第 4 態といわれる。一口にいえ注圧縮可能 な流体様のもので，電気の良導体という性質をもつ物 質状態である。

プラズマの特性は, 巨視的に注密度・温度・圧力な ぞで表わすが，同時に電磁気的諸性質（電気伝導度・ 磁気的粘性など）を加える。その特異な性質をいくつ かのベて，宇宙空間の理解に役立てよう。というのは 宇宙はいたるところがプラズマに満たされているから である。まず，プラズマが電磁気的に中性の場所仡 るときは，ふつうの流体の性質そのままである。とこ ろがいつたん磁場の中にはいると，固体のような弾性 をもつようになる。この性質のため, 太陽プラズマが 地球磁場に遭遇すると，相互に圧力を㧍よぼす。

実際，観測によれば太陽からは太陽風といって，プ ラズマが秒速 300 700km の速度で放射されている。 その圧力によつて地球磁場は長い尻尾になつてなびい ているのである。またいつたん磁場の中に進入したプ ラズマは，こんどは容易にはそこから逃げだせなくな る。これもプラズマと磁場との特有な性質で, この状 態にあるのがバンアレン帯なのである。

\section{3-2 地球の形状}

地球の周囲を回わつている人工衛星の運動状態によ つて，地球の重力場の様子を知ることができる。そ の解析から平均海水面化相当する等ポテンシャル面が えられる。これは地球の平均的形状を示すものであ る。それによると地球の赤道半径は従来の公式值より $288 \mathrm{~m}$ 短かく, 極半径は $137 \mathrm{~m}$ 短かい。方なわち, 地球は 実際に洼従来考えていたのより全体としては小さく， 
その赤道部のふくらみはこれまた従来知られていたの より少ない。

このふくらみは約 1 億年むかしの，地球がいまより 早い自転運動をしていた当時の，平衡形状に相当する という。

さらにこまかく地球の形状を計算した結果では, 地 球は西洋なし形だとか, 地球赤道の断面は長円形にな つているなどといわれる。たしかにそのような特性を もつが，これは地殼 (陸地) と大洋底との岩石の質の ちがいからくる平均的結果のいたずらのようである。 地球の平均海水面にあたる等ポテンシャル面はいわゆ る地球の回転だ円体（基準面）に対して，上下に数十 $\mathrm{m}$ 程度のでこぼこがある。一般に大洋は盛上り, 大陸 ではへこんでいる。日本の南, 西太平洋法基準面より 60 70m高い。イギリス沖の北太西洋, 南アフリカの 沖, 昭和基地の北方などは $50 \sim 60 \mathrm{~m}$ 高い，これに対 し，インドは70 90m も基準面より低い。同様に中央 シベリア, 中央アメリカの両側, 南極大陸のロス海側 など50〜60m低い。このことはいわゆるアイソスタシ 一 (地款平衡) を示すものである。

このように力学的に地球の形状を求める他に, 測地 衛星を利用して地球の幾何学的な形状が精密に測量さ れつつある。半径 $6,000 \mathrm{~km}$ を越える地球の形を, なぜ 士10mといつたこまかいところまで決める必要がある かといらことになるが，それは学術的に必要なばかり でなく, 将来実用的に役立つためである。現在の予想 によれば, 大洋中の船舶や全世界の空を飛ぶ航空機は 航行衛星を利用して自分の地上位置を知ることができ るが, 計算に $1 \sim 2$ 時間もかかる。それを数秒以内に できるよらにしよらと開発されつつある。そのために は，重力場および地球の幾何学的形状が十分こまかく 知られる必要がある。

\section{3-3 目にはみえない天体}

1962年のことである。アメリカで, 月の岩石を調べ るため, ロケットを大気圈外にあげて, X線検出器で 月を観測した。月のX線は予想外に弱くて観測にかか らなかつた。その代わりにすばらしい副産物をとらえ た。「さそり」座のあたりに，強いX線を出す天体が 数個発見された。地上からみたのでは, そのX線源の あたりには，別に目立つた天体は見当たらない。すな わち, 可視光線でみたのでは目立たないのに, X線で は物凄く輝いて見えるのである。

このように可視光線よりX線の方が強い天体は, そ の温度が非常に高温でなければならない。さもなけれ ば，何か特別な条件をもつ状態の下にあることで，常
態とは考えられない（中性子星などの説もあつた）。 表面温度が 6,000 度の太陽では, 可視光線にくらべて X線の強さはわずかに 100 万分の 1 以下である。温度 が高いほど，X 線の強さは可視光線より強くなる。 「さそり」座 X-1 とよばれるX線源は, 全天で最強と いわれるが，可視光線にくらべてX線は100 1, 000倍 の強さである。もしそれが温度によるとすれば何千万 度ないし何億度である。

このさそり座X-1の正体を捕えたのは，わが国の科 学者たちであつた。東大宇宙航空研究所の小田稔教授 は，考案のX線望遠鏡をロケットに積み，その位置を 精密に決定した。また東京天文台の大沢清輝教授は岡 山天体物理観測所の大反射鏡 (口径 $2 \mathrm{~m}$ ) をその位置 に向け，X線源の正体を世界にさきがけて捕えた。

それはかすかな (13等級) 青色の星であつた。それ がどのような機構で, あのようにX線を強く出してい るかはいまのところなお不明である。X線源でその発 生機構の判明しているものに，かに星雲がある。これ は約 900 年のむかし大爆発を抗こした超新星の名残り であるが，いまだに膨張を続けているといら特殊な状 態にある。同様な超新星の残骸と考えられるX線天体 が他に 3 個知られている。

X線を出す別の種類に特殊な状態にある島宇宙があ る。この種のものは電波源として発見されたもので, 望遠鏡でみたところでは, 衝突または爆発しているら しい情景を呈している。また，あるものは巨大なジェ ットを噴出している。ふつうの島宇宙では X線は観測 されないから，これまた特別な状態にある島宇宙であ る。

さそり座 X-1 は数千度以上といら高温の電離ガス (プラズマ)がむき出しにみえている状態らしく,よ ほど特異な状況の星らしい。この種のものと思われる ものがなお十数個知られているが，その大部分が可視 光線による正体は捕えられていない。このX線で泣み えても目には見えない星もいずれはその正体が判明す るであろう。それは星の進化媇しい問題を投じるも のであるかも知れない。

\section{3-4 月・惑星の探査}

アメリカではこの数年内に人間を月に送るという。 それだけに月の研究は急速にそして大規模に進められ ている。

最初のころは, 長大な長円軌道を画く人工衛星を月 に接近させ, 月の写真を撮つて, それを地球に電送さ せた。永久にみることはできないものだといわれた月 の裏も解明されたのであつた。さらに，月面に衝突す 
る直前まで月面写真をとり，それを地球に送らせると いつた方法で，詳細な写真が撮られた。さらに棌衛星 (月の衛星) によつて, 自由に必要な場所の撮影を行

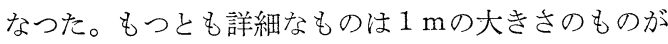
見別けられる。

さらに,月面に軟着する月探査機も出現した。 $1 \mathrm{~mm}$ の小粒な砂まで分解されている。また月の土質の粗密 度や粘性までも調べることができた。月震計をいずれ は持ちこんで，月で起こる月震が火山性のものか隕石 性のものかを調べることになろら。1 20m の大きさ の漂石群があるが，水浮よる浸食ではなく，隕石や流 星物質の衝撃によるものらしい。

地球以外の天体に生命を見出すことは，生命の本質 を究めるために重要な問題である。これを地上の生命 と比較すれば，生命現象の普遍性を捕えることができ るかも知れない。天文学的推論によれば，宇宙全体に は地球と同様に生命が発生し進化している惑星が多数 あつてよい。半径 1,000 光年の範囲内には，現在地上 にある最大級の電波望遠鏡なら相互に通信可能な知的 生命がすむ恒星系が，50\%の確率で存在する計算にな る。だが交信するとすれば時間的に不可能に近い。

そこで太陽系内の天体が問題になる。月や火星は地 球に近く, その環境が似ているので, 生命発生の可能 性が考えられる。アメリカではいろいろな生命検出器 が考案され開発されている。地上では大気中の微生物 がどの高さまであるかを試験的に検出実験を行なつて 好成績を挙げている。いろいろな方法をまとめて総合 的生命検出器が開発されつつあり，いずれは月・火星 などに送りこまれることであろう。

\section{4. 実用上の成果}

\section{4-1 通信衛星}

宇宙空間の性質が明かにされて，これを人間の福祉 に利用した最初は通信衛星であつた。現在の国際通信 （無線および海底電線）はあまり混みすぎて，社会的 需要に忘じきれない状態にある。これを救ら方法は海 底電線の増設の他汭なかつた。ころが人工衛星利用 の宇宙中継の方が経済的だといわれるようになり，そ の実用化が始つた。その最初の公開試験が日米間で行 なわれたとき，それがケネディ大統領の遭難であつた ことは記憶に新しいところであろう。

各国の海外通信会社の出資によって暫定的にできた 国際商業通信衛星組織 (Intersat) では, アメリカの 出資の割合が全体の $51 \%$ 以上で，残りが各国に分割さ れているとのことである。1970年にこの条約の改訂恒 久化が行なわれるというので，各国ともその際に有利
な条件をと懸命な努力がなされている。フランス自体 およびョーロッパ宇宙会議などが自ら通信衛星を開発 しょうとしていることがそれである。

他方，ソ連では Intersat に加入せず，独自の通信 衛星モルニアを打上げて，モスコーとシベリアとを結 んでいる。フランスはこれにも加入することを考えて いるようだ。

国連では宇宙開発による福祉を全世界に配分するこ とに努力している。その一斑として，印度洋を巡る国 々に対し食糧問題・人口問題を, 通信衛星や気象衛星 を活用して，宣伝教育しょうと考えている。

こうした特殊な問題にかかわらず，宇宙中継によれ ば，国境を越えた人間同志の意志疎通に役立ち，国際 間の理解を高めるのに役立つことができよう。こうし た理想に対し，日本はその地域的関係からも，またそ の国力からも，積極的に参画するべきではなからら か。

\section{4-2 気象衛星}

静止衛星が連続撮影した地球をみると，驚くばかり に雲の移動消長の姿がよくわかる。台風の大きな渦巻 き, 猛烈な速度で走るジェット気流の帯, 竜巻きを示 寸特殊の雲の発生, 山脈による雲の消長など, 手に取 るようである。これは気像衛星のとつたものの映画で あるが，これらは予報を正確にし，予報を長期化する ことに役立つであろう。

わが国などでは，台風の時々刻々の動きをとらえる のに何物にも優る効果があろう。始めのころは昼間だ けであつたが，赤外線写真が開発されてから液間も 観測可能となつた。集中豪雨の発見も可能だろうとい 5。

こうした気象衛星の実際利用については，世界気象 機構がこれに当たるよう，国際的に促進されつつあ る。その実施のあかつきには, 西太平洋地域センター としての役割をわが国が果さね效なるまい。

4-3 その他の宇宙利用

地球の幾何学的形状を測定するため, 特殊な精密測 定用の測地衛星が各種開発されて使われている。当初 アメリカでは軍用として開発された。いまでは国際協 力とくに米ソが先頭に立つて，国際的に測定が拡大さ れつつある。

航行衛星は天文航法に代わり，いかなる天候のとき でも艦船・航空機の位置を決定できるために利用され ているものである。現在は軍用であるが，将来いずれ は一般人の利用に供されるようになる。

現在自らの位置を知るためには，この衛星を利用し 
て 1 2 時間もかかるという。将来計画として，質問 電波を発射すれば，それが衛星によつて中継され，本 部で計算され，数秒で返事が返つてくるといつたシス テムが開発されつつある。このようになれば，錯そう する航空機の交通管制にも役立てらると考えられてい る。

高空から地球を撮影したもの，とくにそのカラー写 真汸いらろな方面に役立つ。実験デー夕によると， 鉱物資源の所在，海流の温度を調へて漁業への効用， 水路の発見, 水資源の存在, 湖の水質推定などが成功 している。将来の開発にまつものであるが，すこぶる 有用で幽ろら。資源衛星とょばれている。

\section{4-3 宇宙基地}

人工衛星に観測基地を設定する案がある。有人の場 合をアメリカでは MOL 計画とよんで企面を進めてい る。他方，月面上に基地を設置する考え方も岁る。

これらの宇宙空間基地では, 物体の重量が地上での 值と非常にちがうことが特徴である。もちろん，地上 のような大気や電離層による障害がないので, 観測に 最適である。たとえげ，大望遠鏡を設置するとすれ ば，その構造や取り扱いが非常に楽になる。月面上な ら重量が地上の值の $1 / 6$ であるし，人工衛星上なら 0 である。それが地上にある最大級の口径のものなら， 宇宙の極限まで見通せるであるう。

また，こうした基地は地上の災害監視所として利用 されると考えられている。こうなると地上の秘密施設 などは無意味になろう。

4-4 波及效果

宇宙開発によつてえられた科学技術の成果が，日常 生活の諸分野へ応用される波及効果は, 案外多方面に およんでいる。驚いたことにそれは, 製造工業・保健 衛生・国防・建設工業・電力・資源・電気・運輸 - 食 品農業・教育厚生・社会政治など，あらゆる分野にわ たる。米国航空宇宙局の議会に提出した報告書による と，その数 200 種住しようとするほどもある。

これらはすべて研究開発の過程でえられた成果の応 用である。技術協力のみに頼り自力開発をしない限 り，こうした利得沈られない。しかも波及効果によ る新生品が続々出現して，全世界のあらゆる分野をゆ すぶるのである。それ注宇宙開発そのものに劣らない 大きな効果をもつ。恐るべきことである。いくつかの 例示をつぎに示す。

（1）月の成因を調べるため月面に送る月震計は原 爆地下爆発探知器として応用されている。

（2）数千の電気回路をわずか 100 円銀貨大の容積
内に收为た集積回路 (IC); そ社使つて $30 \mathrm{~cm}$ 立方の 中に大型計算装置と同等な働きをもつ超小型電子計算 装置吕作られた。

(3) 直径 100 オングストロームの細い電線。

(4) 誘導に使うジャイロの力学的平衡をとるため に応用されたルビー・レーサーの利用。

（5）極超低温用ジャイロに応用した超電導合金。

（6）ジェムニ宇宙船から写した地球のカラー写真 の応用（地質・地理・土木一ダム，八イウェー, 橋，パイプ路線，都市開発など)。

（7）通信衛星の商業通信衛星網（52万国参加） の応用。

（8）ロケットの自動検查修理装置の電話ケーブル 修理一の応用。

（9）気象衛星による全世界網（地球上 200 ケ所に およ糸自動画象通信装置あり)。

（10）人工衛星により波浪党観測しての波浪予報。

（11）高純度の金属より高温にたえる磁性，それの 計算装置一の応用。

（12）高温にたえる電池 $\left(350^{\circ} \sim 650^{\circ} \mathrm{C}\right)$ 。

\section{5. 日本の宇宙開発}

5-1 科学技術の独立

わが国は国土は狭く，資源に恵まれず，乙かも人口 が多い。その上，第 2 次世界戦争での敗北で，国土は さらに狭められ，荒廃したのであつた。それにもかか わらず，今日みるように見事に德興し，世界でも屈指 の工業国に発展した。努力もあるが科学技術の賜だと 思う。

だが，その発展はわれわれ独自の実力だけであつた ろうか。むしろ外国との技術提携に負うものが多かつ たのではなかららか。科学も技術も海外より受ける方 が，与える方より多かつたこと碓かである。それは いままで，もつとも安価な方法であつたが，いつまで も続くとは考えられない所問題がある。

科学技術の最近の進歩はあまりに速く，その進歩の 跡を追うだけでも，いままでのようにはいかなくなる であろら。いまのうちに，自らの科学技郝を持つため に，また自ら独力で研究開発する能力を養らために， 必要な投資を行なわないと，海を将来代残すことにな ろう。

だからといつて，全面的海外との技術提携を拒否 するというのではない。発展の段階として，止むをえ ない場合も㐫万ら。だが真の国際協力一一技術提携は 自らの実力・成果をもつていて始文て成立するもので ある。自らの科学技術を独立にもつことは容易なこと 
ではないが，持たねばならない。科学技術の独立性を 失つたとき，国は転落する他はないからである。

ここで思いおこすのは，IGYの始る前，わが国でも 何とか観測ロケットを打上げたいとの希望があつた。 そのころ米国ではV2 2 ロケットを使つて, 超高層に関 する数々の成果発表していた。この方面の研究は口 ケットなしでは手も足も出ない状況であつた。

そこで，わが学界では口ケットを米国から供与して もらら案もあつたが，たまたま，当時糸川教授が小型 ロケットの研究に手をつけていたので，それを急拠推 進するよう要請することになつた。もしもこのとき, 研究自体を米国に依存しわが国ではその跡を追うと か，または米国からロケットを購入して間に合せると かであつたなら，わが国の今日の宇宙空間の研究開発 は惨めなものであつたろら。

自らの科学技術を培うためには，科学技術の全般的 水準を上げる必要がある。そのためには当然一般的に あらゆる科学技術の分野の振興を計るべきであるが, 同時に必要な巨大科学の推進を計る方策がある。その 巨大科学の一つが宁宙開発である。

\section{5-2 巨大科学としての宇宙開発}

かつて弾争が科学技術の飛躍的発展の動機となつ ていた。それは非常時ということで，金に糸目をつけ ず，あらゆる専門家を自由に動員し組織できたからで ある。第 2 次世界戦争で産れた電子計算装置, レー ダー, 原子力解放, 自動操縦理論など数えきれない。

平時にあつて同様な効果を果すものが巨大科学であ る。それによる以外には勂破できないような研究開発 であつて，これを巨大科学として採り上げてそれを解 決する過程にその秘密がある。すなわち, 十分な経費 ・施設, あらゆ曺門分野の組織的協力, そして全体 を企画調整し評価する推進機関である。

このよらにして，それは容易ではないが，巨大科学 は音速の壁を破るのである。一度これを突破すれば, その先には平穏な超音速の世界がひらけているのであ る。巨大科学でなくては，この新しい世界には手がと どかないのだ。

わが国の宇宙科学の始りは, 大学における自然科学 的研究として観測ロケットによる観測であつた。たま たまそれが東京大学の生産技術研究所で総合的組織的 に開発されたことが，今日の発展をもたらした要因だ と考えられる。

最近になつて, 宇宙科学の自然科学的研究の他に, いろいろな実用的開発が要望され, 人工衛星打上げの 気運も高まつてきた。こうなると, その全部を大学で
担当することは困難になつた。大学には大学の使命が あるからである。またそれはもはや自由研究ではない からである。すなわち, 責任の問題がはいつてくる。 トップ・マネージャーとしては, 総合的調整を行ない ながら推進し目的を達成する責任がある。また各研究 開発の分担者相互の間にも，それぞれ責任と義務とを 別ち合わ祇ばならない。

巨大科学のもら一つの特徴は，国民の支持が必要な ことである。普通の研究では個々に国民の支持をらけ るまでもないが，巨大科学はその経費が大きいだけ に, 税負担者である国民の支持功必要となる。学界と か産業界はもちろん, 政府・国会の支持が必要だと思 ら。それらの支持をえて始めて巨大科学として成立す るのである。

巨大科学は一般的な研究索纴迫するといつた狭量な 見方もある。だが，一歩進めて考えると，巨大科学は 一般的な研究の推進役であり, その発展亡相俟つて科 学技術全体の発展がある。いずれを欠いても，全体の 発展法期されない。この意味でも宇宙開発注科学にお いても技術においても，広い裙野をもつているので, 巨大科学としてふさわしいものの一つである。

5-3 宇宙開発として何をするか

アメリカでは宇宙開発予算はすでに山越して減少 しつつある。人間を月に送るアポロ計画だけはいささ かの削減もないが……これに歩調を合わすように大 学院の学生数も減じている。生物・生命の分野へ移り つつあるといら，いわば宇宙開発は飽和㹜態に達し定 常化してきたといえよう。

こんな時期に，日本が宇宙開発に力夌入れて何をす るのかと反問される。流行を追らためにやるのではな い。学術上からも, 国家の利益の上からも, 必要だと 判断されるからである。宇宙開発からえられる科学技 術上の新しい知識だけでも，十分これを進める価值が ある。その上, 宇宙空間の実用面が限りない福祉をも たらすのである。他国の顔色をみるまでもない。確信 をもつて進めるべきである。

ところが，一般の人々は現実的な問題に重点をお く。たとえば, 1970年には商業通信衛星公社(Intersat) が恒久的協定の下に正式に発足する。それにつけ，よ り有利な協定を結ぶために, 欧州でもわが国でも通信 衛星を打ち上げて発言権を確保す心゙きだとの動きがあ る。

このような問題はそれぞれ所管の省庁の責任で, 国 策として推進すべきものであろら。通信の他に, 気象 ・航行・測地・資源など,さささざなな実用衛星を打上 
げる必要が要請されている。いずれも必要なものであ ろう。

他方，たんに必要だからといって，すべてをわが国 で研究開発しなければならない理由はないといら考え 方もある。できるだけ国際的に，または地域的に共同 して開発すべきだというのである。わが国專用のもの とも考え合せ，その軽重・緩急を勘案して，慎重に評 価する必要がある。

\section{5-4 開発体制をどうするか}

わが国の研究開発体制については，L4S 失敗以来, いわゆる一本化または一元化という問題が起こつた。 ところが，更地に新しく家を建てるのとちがつて，そ こにはすでに幾本かの柱が立つていたというのが，わ が国の宇宙開発の現状である。大柱の 1 本は東大の宇 宙航空研究所を中心にしたものであり, 他の 1 本は科 学技術庁の宇宙開発推進本部を中心にしたものであ る。それにいくつかの柱が各省庁の進めている実用衛 星関係の研究計画である。

一本化とか一元化といえば，この大柱をまず一つに することで，いずれかが他を吸収するか，両者を強い 協力関係にするかであろう。その前提として問題にな るのは果してL4Sロケットは人工衛星の試験打上げが できるかという点である。とても上るはずがないとま でいいきる人さえある。だが，当事者たちは黙々とや つているが，自信満々である。いずれと判断するかは 自由だが，当事者のいうことを信じる他はなからう。 どうしても成功してもらわないと，M-ロケット計画 まで行き声まることになろう。

つぎの問題は科学技術庁の計画による静止衛星が, これまた昭和48年度まで打上げられるかという点で ある。このためには N-ロケット（径 $2.4 \mathrm{~m}$ ）の開発 や，従来わが国ではあまり経験のない誘導制御技術の 開発が必要になる。よほどの速度で開発を進めない限 り間に合わない。とはいえ，全面的にアメリカの協力 を受けるのでは意味がないと思うのである。
N-ロケットは，M-ロケットのように全段が固体燃 料ではなく，第 3 段目には液体燃料を使うことになつ ている。液体然料は誘導制御を精密に行ならために必 要なのだという。液体然料と誘導制御とはわが国とし ては新しい開発に当たる。固体燃料ロケットの L, M 系列の経験や知識がどれだけそれに生かせるかも問題 になる。

このような状勢だから, 両陣営の技術者・科学者が 別々になつて対抗するのでは問題にならない互に有機 的に協力するのでなくては開発の成功は難しい。

そこで問題は，いかにその協力を円滑に行なうかに かかる。官・学・民が卒直に手をつないで，巨大科学 の研究開発を進めることは，これがわが国における巨 大科学のテスト・ケースであるだけに, 重要な課題で ある。これをらまく進めることは，国益からみても， また大学自らのためにも，喜ぶべきことである。

巨大科学の体制は, 縌の命令系統でつなぐのではな く，むしろ関倸するあらゅる専門が並列に横につなが るやり方がふさわしい。わが国の宇宙開発は各省庁所 管分野が並列である。この場合, 総合的に全体の企画 調整, 評価推進を注る機関が必要で, ここで一元化 または一本化が行なわれるのである。わが国の宇宙開 発では新たに宇宙開発委員会が発足し，これに答える ことになつている。

こうしたルーズな一体的結びつきで研究開発を進め ることは，それぞれの専門の自主性と責任をお互に尊 重しつつ，扶け合い補い合い，よりよく協力するため である。

好むと好まざるにかかわらず，科学技術は進歩す る。革新䩢。世の中はこうして変化する。思想も哲 学も, 政治も経済も変わる。それは科学技術が有能だ からである。有能なものはそれだけ有益である。だ が，同時に一歩誤れば有害となる。この点を極度にお それる人々のために，わが国の宇宙開発は「平和目的 に限る」ことなつていることを附記して稿をおえる。 


\title{
Some Problems on the Space Activities in Japan
}

\author{
by Masasi Miyadi \\ (Special Committee on Space Research, Science Council of Japan)
}

\begin{abstract}
SYNOPSIS:-Since the first artificial satellite was launched by U.S.S.R. in October, 1957, a great emphasis has been placed on the space research activities throughout the world.

In Japan, the Institute of Space and Aeronautical Science, University of Tokyo and Science and Technology Agency are playing a most active part in the space research activities.

The author describes the history and background of the space research and development in the past decade, and discusses some problems at which Japan is facing to further promote her space activities.
\end{abstract}

